Situs Jurnal : $\underline{\text { http://ejournal.stiepancasetia.ac.id/index.php/jieb }}$

Jilid 5 Nomor 2 Juli 2019

Hal 191 - 199

\title{
UPAYA PIMPINAN DALAM MENINGKATKAN KINERJA PENYIAR PADA RADIO SWARA BERSUJUD 89,8 FM
}

\begin{abstract}
Arifia Nurriqli*
Abstract: The purpose of this study is to study the expenditures that must be made above the increasing support of Swara Bersujud Radio announcer $89.8 \mathrm{FM}$, and to find out the developments made in improving the performance of broadcasters on Swara Bersujud Radio 89.8 FM. The method used in this research is qualitative method. This research was conducted on Broadcasters on Swara Bersujud Radio 89.8 FM. Data is collected through observation, interviews, and documentation. The results of this study are the efforts made so far carried out Swara Bersujud Radio 89.8 FM in improving employee performance through work communication and giving warning. Efforts made by the leaders of Swara Bersujud Radio 89.8 FM are training, job change, promotion, counseling
\end{abstract}

Keywords: Leadership, Performance, radio

Abstrak: Tujuan dari penelitian ini adalah untuk mengetahui upaya yang selama ini dilakukan pimpinan dalam meningkatkan kinerja penyiar pada Radio Swara Bersujud 89,8 FM, dan untuk mengetahui upaya yang seharusnya dilakukan pimpinan dalam meningkatkan kinerja penyiar pada Radio Swara Bersujud 89,8 FM. Metode yang digunakan dalam penelitian ini adalah metode kualitatif. Penelitian ini dilakukan terhadap Penyiar Pada Radio Swara Bersujud 89,8 FM. Data dikumpulkan melalui observasi, wawancara, serta dokumentasi. Hasil penelitian ini adalah Upaya yang selama ini dilakukan pimpinan Radio Swara Bersujud 89,8 FM dalam meningkatkan kinerja pegawai adalah melalui orientasi kerja dan pemberian teguran. Upaya yang seharusnya dilakukan pimpinan Radio Swara Bersujud 89,8 FM adalah pelatihan, rotasi jabatan, promosi, konseling.

Kata kunci : Pimpinan, Kinerja, radio

\section{Latar Belakang}

Suatu organisasi atau instansi baik pemerintah maupun swasta harus bisa meningkatkan kualitas kinerja karyawan yang dimiliki, karena karyawan adalah aset yang paling penting dalam suatu organisasi. Supaya karyawan dapat memberikan kinerja yang baik maka suatu organisasi swasta atau instansi pemerintah harus dapat memberikan dukungan yang baik kepada karyawan.

Menurut Syamsir Torang (2013:74) kinerja (performance) adalah kuantitas dan atau kualitas hasil kerja individu atau sekelompok didalam organisasi dalam melaksanakan tugas pokok dan fungsi yang berpedoman pada norma, standar operasional prosedur, kriteria dan ukuran yang telah ditetapkan atau yang berlaku dalam organisasi. Mempunyai kinerja yang baik adalah keinginan setiap organisasi, jika terciptanya kinerja yang baik maka akan terciptanya hubungan yang harmonis, suasana kerja yang sangat menyenangkan dalam terciptanya tujuan. 
Peningkatan kinerja karyawan yang baik akan membawa kemajuan bagi suatu organisasi swasta atau instansi pemerintah untuk dapat mencapai tujuan organisasi. Oleh sebab itu berbagai upaya-upaya untuk meningkatkan kinerja karyawan merupakan hal yang paling serius karena dengan keberhasilan untuk mencapai tujuan dan kelangsungan hidup suatu organisasi swasta atau instansi pemerintah tergantung pada sumber daya manusia yang ada didalam suatu organisasi swasta atau instansi pemerintah tersebut.

Radio sebagai salah satu media massa memiliki karakteristik cepat dalam menyampaikan pesan, luas jangkauannya dalam arti tidak mengenal medan, tidak terikat waktu, ringan dan dapat dibawa kemanapun, murah dan tidak memerlukan banyak konsentrasi karena radio hanya untuk didengarkan. Dengan merujuk menurut Peraturan Pemerintah No: 55 tahun 1977, Radio Siaran adalah pemancar radio yang langsung ditujukan kepada umum dalam bentuk suara dan mempergunakan gelombang radio sebagai media. (Effendy, 2011:187).

Ketika berbicara tentang radio, kita tidak bisa lepas dari penyiar, karena penyiar adalah ujung tombak radio. Mewakili radio, ia berinteraksi langsung dengan pendengar. Baik-buruk siarannya atau bahkan perilakunya berpengaruh terhadap baik-buruk atau integritas radionya. Sukses tidaknya sebuah acara ditentukan oleh penyiarnya. Penyiar adalah orang yang menyampaikan berita atau informasi kepada para pendengar. Materi siaran tersebut adalah hasil yang telah diolah oleh tim kreatif siaran berdasarkan program yang telah disusun oleh devisi program. Sampainya sebuah acara kepada para pendengar adalah hasil kerja sama penyiar, devisi program, dan tim kreatif.

Seorang penyiar mampu membawakan program siaran dengan format yang sudah ditentukan oleh pihak radio. Bahkan terkadang mereka juga harus memformat sendiri program siaran yang dibawakannya agar lebih menarik dan mampu menyedot banyak pendengar. Disinilah peran seorang penyiar berada. Semenarik apapun program acaranya jika si penyiar tidak dapat membawakannya dengan baik, maka tidak diragukan lagi bahwa pendengar akan segan untuk mendengarkannya. Sebaliknya, jika penyiar bisa mengemas sebuah program acara semenarik mungkin bagi pendengar, maka dia akan mendapat banyak sorotan. Memang, yang paling membedakan dalam menyajikan acara siaran di radio adalah suara manusia.

Radio Swara Bersujud 89,8 FM merupakan salah satu radio pemerintah yang ada di Batulicin Kabupaten Tanah Bumbu Kalimantan Selatan. Dalam menjaga eksistensi Radio Swara Bersujud 89,8 FM, pimpinan telah melakukan beberapa cara untuk menjaga kualitas penyiarnya seperti melakukan pembekalan pada penyiar baru. Pembekalan tersebut dalam bentuk pemberian pelatihan tentang teknik penyiaran dan prosedur penyiaran. Tetapi pada aktualnya kualitas penyiar belum sesuai dengan yang ditargetkan Radio Swara Bersujud 89,8 FM, hal ini dilihat dari masih adanya penyiar yang blank saat acara berlangsung, intonasi yang kurang jelas, dan penyiar melakukan penyiaran tidak sesuai aturan dasar penyiaran.

Dengan melihat latar belakang tersebut, maka peneliti tertarik untuk meneliti mengenai "Upaya Pimpinan Dalam Meningkatkan Kinerja Penyiar Pada Radio Swara Bersujud 89,8 FM". Dari dasar latar belakang yang telah dikemukakan di atas, maka pokok permasalahan ini adalah:

1. Bagaimana upaya yang selama ini dilakukan pimpinan dalam meningkatkan kinerja penyiar pada Radio Swara Bersujud 89,8 FM?

2. Bagaimana upaya yang seharusnya dilakukan pimpinan dalam meningkatkan kinerja penyiar pada Radio Swara Bersujud 89,8 FM?

\section{Kajian Literatur}

Manajemen sumber daya manusia adalah suatu proses yang terdiri atas perencanaan, pengorganisasian, kepemimpinan dan pengendalian kegiatan-kegiatan yang berkaitan dengan 
analisis pekerjaan, evaluasi pekerjaan, pengadaan, pengembangan, kompensasi, promosi dan pemutusan hubungan kerja guna mencapai tujuan yang telah ditetapkan (Panggabean, 2010:15). Menurut Siagian (2012:128), Manajemen sumber daya manusia adalah konsep-konsep yang digunakan sebagai titik tolak berpikir dan bertindak dalam merumuskan kebijaksanaan yang menyangkut manusia dalam organisasi, serta praktek-praktek yang seyogyanya diterapkan, yang menyangkut kehidupan berkarya dalam organisasi. Berdasarkan teori di atas, maka dapat disimpulkan bahwa manajemen sumber daya manusia adalah suatu proses perencanaan, pengorganisasian, kepemimpinan dan pengendalian kegiatan- kegiatan dalam merumuskan kebijaksanaan yang menyangkut manusia dalam organisasi.

Pengembangan tenaga kerja adalah program yang khusus dirancang oleh suatu organisasi dengan tujuan membantu karyawan dalam meningkatkan kemampuan, pengetahuan, dan memperbaiki sikapnya. Berbagai aktivitas yang dapat dilakukan oleh suatu organisasi untuk mengembangkan tenaga kerja, yaitu :

1. Pelatihan/ Pendidikan

Rahasia keberhasilan suatu organisasi yang paling efektif banyak tergantung kepada penerapan latihan bagi tenaga kerja dalam organisasi tersebut. Pelatihan/ pendidikan dewasa ini dianggap bukan lagi merupakan investasi yang tidak produktif. Manajemen yang efektif melihat latihan/ pendidikan sebagai investasi jangka panjang pada sumber daya manusia.

2. Rotasi Jabatan

Rotasi jabatan sesungguhnya tidak lain daripada salah satu cara latihan / pendidikan. Dengan rotasi jabatan seorang karyawan ditugaskan memegang jabatan yang berbeda dari satu waktu ke waktu yang lain, selain agar karyawan memahami pelaksanaan berbagai tugas, agar ia memperoleh pengetahuan yang lebih luas mengenai berbagai jabatan. Rotasi jabatan sering diterapkan kepada para manajer, sebagai usaha mengembangkan manajer.

3. Delegasi

Manajer yang tidak berani mendelegasi kepada bawahan, mengurangi efektivitas manajer itu sendiri. Manajemen adalah mencapai hasil melalui orang lain, karenanya untuk dapat merealisasi itu, delegasi oleh manajer mutlak perlu. Salah satu kualifikasi penting dari seorang manajer adalah kesanggupan mendelegaskan sebagian tugas dan wewenang kepada bawahannya. Tugas-tugas manajer baik ditinjau dari sudut proses, maupun dari sudut bidang, sebagian atau seluruhnya dapat didelegasi.

4. Promosi

Promosi adalah kegiatan pemindahan karyawan dari satu jabatan ke jabatan yang lebih tinggi, di mana tugas, wewenang, dan tanggung jawab lebih tinggi dari sebelumnya. Ini dilakukan demi perkembangan karyawan selanjutnya karena pada jabatan sebelumnya ia telah menunjukkan prestasi yang optimal, dan kalau tetap berada pada jabatan lama akan menimbulkan kebosanan.

5. Pemindahan

Pemindahan atau transfer adalah kegiatan mengganti karyawan yang setingkat. Dalam hal ini, kelompok kerja, tempat kerja, atau kesatuan organisasi pegawai diubah dengan tujuan perhatian, kemampuan, dan kerja sama dapat meningkat.bila pegawai dipindahkan ke jabatan yang sesuai dengan perhatian dan kemampuan pegawai yang bersangkutan.

6. Konseling

Dalam setiap organisasi, karyawan dapat dibagi atas dua macam, yaitu penasehat dan yang dinasehati. Umumnya para manajer termasuk kepada kelompok penasihat, yaitu penasihat- penasihat bagi bawahannya khususnya yang berhubungan dengan pelaksanaan pekerjaan bawahan tersebut demi semakin terampilnya para karyawan yang 
bersangkutan. Situasi yang berbeda-beda, meminta kesediaan para manajer untuk mengerti, empati dan mempertimbangkan karyawan demi perkembangan karyawan untuk masa yang akan datang. Setiap karyawan yang ingin meminta pertolongan dalam hubungannya dengan pekerjaannya, maka manajer harus dapat memberi saran dan nasihat-nasihat, bahkan persoalan pribadi yang dimintai nasihat oleh bawahan, manajer harus memberi penuh simpatinya.

7. Konferensi

Ikut serta dalam suatu konferensi bagi seseorang akan banyak memberi pengalaman, pengtahuan, dalam berbagai bidang dan menambah keterampilan. Cara menyelenggarakan konferensi, proses cepat, cara diskusi, dan pengambilan berbagai keputusan akan membawa dampak pada setiap orang yang turut dalam suatu konferensi. Khusus kepada para manajer, konferensi membawa deampak positif dalam perkembangan para manajer tersebut.

Secara harfiah kepemimpinan atau leadership berarti adalah sifat, kapasitas dan kemampuan seseorang dalam memimpin. Arti dari kepemimpinan sendiri sangat luas dan bervariasi berdasarkan para ilmuwan yang menjelaskannya. Menurut Charteris-Black (2015:30), definisi dari kepemimpinan adalah "leadership is process whereby an individual influence a group of individuals to achieve a common goal". Kepemimpinan adalah sifat dan nilai yang dimiliki oleh seorang leader. Teory kepemimpinan telah berkembang sejak puluhan tahun yang lalu dan sudah banyak berbagai referensi dalam bentuk beraneka macam mengenai topik ini yang dihasilkan dari berbagai penelitian. Fungsi kepemimpinan dalam sebuah organisasi atau kelompok sangat penting karena fungsi kepemimpinanlah sebuah organisasi dapat mencapai tujuannya melalui jalan dan cara yang benar. Memahami dengan baik mengenai konsep kepemimpinan sangat membantu seseorang dan organisasi bekerja lebih efektif dan efisien dalam mencapai tujuan dan kondisi yang diinginkan.

Pelatihan merupakan usaha mengurangi atau menghilangkan terjadinya kesenjangan antara kemampuan karyawan dengan yang dikehendaki organisasi. Usaha tersebut dilakukan melalui peningkatan kemampuan kerja yang dimiliki karyawan dengan cara menambah pengetahuan dan keterampilan serta merubah sikap. Karyawan merupakan kekayaan organisasi yang paling berharga, karena dengan segala potensi yang dimilikinya, karyawan dapat terus dilatih dan dikembangkan, sehingga dapat lebih berdaya guna, prestasinya menjadi semakin optimal untuk mencapai tujuan organisasi.

Terdapat banyak pendekatan untuk pelatihan. Jenis-jenis pelatihan yang dapat diselenggarakan di dalam organisasi menurut Simamora (2013:278) adalah sebagai berikut :

1. Pelatihan Keahlian

Pelatihan keahlian (skills training) merupakan pelatihan yang sering dijumpai di dalam organisasi. Program pelatihannya relatif sederhana, kebutuhan atau kekurangan diidentifikasi melalui penilaian yang jeli Kriteria penilaian efektivitas pelatihan juga berdasarkan pada sasaran yang diidentifikasi dalam tahap penilaian.

2. Pelatihan Ulang

Pelatihan ulang (retraining) adalah subset pelatihan keahlian. Pelatihan ulang berupaya memberikan kepada para karyawan keahlian-keahlian yang mereka butuhkan untuk menghadapi tuntutan kerja yang berubah-ubah. Umpamanya, karyawan-karyawan yang selama ini memakai mesin produksi konvensional mungkin harus dilatih ulang untuk memakai mesin produksi yang terkomputerisasi.

3. Pelatihan Lintas Fungsional

Pada dasarnya, organisasi telah mengembangkan fungsi kerja yang terspesialisasi dan deskripsi pekerjaan yang rinci. Sungguhpun demikian, dewasa ini organisasi lebih menekankan multi keahlian ketimbang spesialisasi. Pelatihan karyawan dalam 
bermacam-macam fungsi menjadi semakin populer. Pelatihan lintas fungsional (cross functional training) melibatkan pelatihan karyawan untuk melakukan aktivitas kerja dalam bidang lainnya selain dari pekerjaan yang ditugaskan.

4. Pelatihan Tim

Dewasa ini terdapat tekanan yang menguat terhadap kinerja tim. Tim manajemen, tim riset, dan satuan tugas temporer merupakan karakteristik yang lazim di banyak organisasi. Tim adalah sekelompok individu yang bekerja sama demi tujuan bersama.

5. Pelatihan Kreativitas

Pelatihan kreativitas (creativity training) berlandaskan pada asumsi bahwa kreativitas dapat dipelajari. Ada beberapa cara untuk mengajarkan kreativitas, yang semuanya berusaha membantu orang-orang dalam memecahkan masalah dengan kiat baru. Salah satu ancangan yang lazim diterapkan adalah brainstorming, dimana para partisipan diberikan peluang untuk mengeluarkan gagasan sebebas mungkin. Setelah gagasan dianggap cukup banyak, para partisipan diminta memberikan penilaian rasional dari segi biaya dan kelaikan. Kreativitas biasanya dianggap mempunyai dua tahap: imajinatif dan praktis. Teknik brainstorming yang diikuti oleh pertimbangan rasional dari opsi-opsi yang dihasilkannya memenuhi kedua tahap tersebut.

Perusahaan dapat berkembang merupakan keinginan setiap individu yang berada di dalam instansi tersebut, sehingga diharapkan dengan perkembangan tersebut instansi mampu bersaing dan mengikuti kemajuan zaman. Karena itu, tujuan yang diharapkan oleh instansi dapat tercapai dengan baik. Kemajuan instansi dipengaruhi oleh faktor-faktor lingkungan yang bersifat internal dan eksternal. Sejauh mana tujuan instansi telah tercapai dapat dilihat dari seberapa besar instansi memenuhi tuntutan lingkungannya. Memenuhi tuntutan lingkungan berarti dapat memanfaatkan kesempatan atau mengatasi tantangan lingkungan atau ancaman dari lingkungan dalam rangka menghadapi atau memenuhi tuntutan dan perubahan-perubahan di lingkungan instansi.

Istilah kinerja berasal dari kata job performance atau actual performance (prestasi kerja dan prestasi sesungguhnya yang dicapai oleh seseorang). Menurut Supriyanto (2013:280) dalam mencapai tujuan yang telah ditetapkan organisasi dapat melakukan usaha-usaha dari sumbernya yang berkualitas. Usaha ini dapat berupa pengembangan, perbaikan sistem kerja, sebagai kelanjutan penilaian terhadap prestasi kerja karyawan yang telah dicapainya dengan kemampuan yang telah dimilikinya pada kondisi tertentu. Dengan demikian kinerja merupakan hasil keterkaitan antara usaha, kemampuan, dan persepsi tugas yang telah dibebankan.

Menurut Anton M. Moeliono (2014:33), pengertian radio adalah siaran (pengiriman) suara atau bunyi melalui udara. Menurut Romli (2013:17), karakteristik khas dari radio adalah:

1. Auditori, Sound Only, Auditif. Radio adalah "suara", untuk didengar, dikonsumsi telinga atau pendengaran. Apa pun yang disampaikan melalui radio harus berbentuk suara, hanya suara, lain tidak.

2. Transmisi. Proses penyebarluasannya atau disampaikan kepada pendengar melalui pemancaran (transmisi).

3. Mengandung gangguan. Seperti timbul-tenggelam (fading) dan gangguan teknis.

4. Theatre of Mind. Radio menciptakan gambar dalam imajinasi pendengar, "memainkan" imajinasi pendengar, dengan kekuatan kata dan suara. Secara harfiah, theater of mind berarti ruang bioskop di dalam pikiran. Radio mampu menggugah imajinasi pendengarnya, dengan suara, musik, vocal atau bunyi-bunyian.

5. Identik dengan musik. Umumnya orang mendengarkan radio untuk mendengarkan musik/lagu. Radio menjadi media utama untuk mendengarkan musik. 
Penyiaran atau dalam bahasa Inggris dikenal sebagai broadcasting adalah keseluruhan proses penyampaian siaran yang dimulai dari penyiapan materi produksi,produksi, penyiapan bahasn siaran, kemudian pemancaran sampai kepada penerimaan tersebut oleh pendengar tau pemirsa di suatau tempat. Dari definisi umum ini, tampak bahwa arti penyiaran berbeda dengan pemancaran. Pemancaran sendiri berarti proses transmisi siaran, baik melalui media udara maupun medi kabel koaksial atau slauran fisik yang lain.(Wahyudi, 2014:6).

\section{Metode Penelitian}

Jenis Penelitian pada skripsi ini adalah penelitian kualitatif. Menurut Bogdan dan Taylor mendefinisikan penelitian kualitatif sebagai penelitian yang menghasilkan data deskripstif berupa kata-kata tertulis, atau lisan dari orang-orang dan perilaku yang dapat diamati (Moleong, 2012:33). Dalam penelitian kualitatif perlu menekankan pada pentingnya kedekatan dengan orang-orang dan situasi penelitian, agar peneliti memperoleh pemahaman jelas tentang realitas dan kondisi kehidupan nyata (Patton dalam Poerwandari, 2013:81).

Populasi dalam penelitian ini adalah seluruh penyiar Radio Swara Bersujud 89,8 FM berjumlah 17 orang.

Berdasarkan populasi tersebut maka penentuan sampel yang representatif dalam penelitian ini adalah menggunakan teknik sampling non-probability sampling dengan teknik sampling jenuh. Teknik sampling jenuh adalah teknik penentuan sampel bila semua anggota populasi digunakan sebagai sampel, hal ini dilakukan bila jumlah populasi kecil kurang dari 30 orang (Sugiyono, 2008:85). Jadi sampel dalam penelitian ini adalah seluruh penyiar Radio Swara Bersujud 89,8 FM sebanyak 17 orang

Adapun data yang digunakan dalam penelitian ini adalah kualitatif dan kuantitatif.

1. Data kualitatif, yaitu data yang disajikan dalam bentuk kata verbal bukan dalam bentuk angka.

2. Data kuantitatif adalah jenis data yang dapat diukur atau dihitung secara langsung, yang berupa informasi atau penjelasan yang dinyatakan dengan bilangan atau berbentuk angka.

Sumber data yang dianalisis dalam penelitian ini meliputi data primer dan data sekunder.

1. Data Primer

Data primer dalam penelitian ini adalah data yang diperoleh langsung dari lapangan. Data ini dapat diperoleh melalui pengamatan langsung maupun hasil wawancara kepada informan berdasarkan pedoman wawancara yang dibuat oleh peneliti.

2. Data Sekunder

Data sekunder dalam penelitian ini didapat melalui peninggalan tertulis yang dilakukan dengan cara membaca buku-buku literatur, dokumen, dan tulisan yang dianggap peneliti berkenan dengan permasalahan yang sedang diteliti.

Untuk mendapatkan kelengkapan informasi yang sesuai dengan fokus penelitian maka yang dijadikan teknik pengumpulan data adalah sebagai berikut:

1. Wawancara; Teknik pengumpulan data melalui tanya jawab langsung dengan informan untuk mendapatkan informasi-informasi tambahan yang berkaitan dnegan penelitian ini.

2. Observasi; Mengamati secara langsung-tanpa mediator-sesuatu objek untuk melihat dengan dekat kegiatan yang dilakukan objek tersebut. Kegiatan observasi meliputi melakukan pengamatan dan pencatatan secara sistematik kejadian-kejadian, perilaku, obyek-obyek yang dilihat dan hal-hal lain yang diperlukan dalam mendukung penelitian yang sedang dilakukan. 
3. Dokumentasi; Mengumpulkan data melalui peninggalan tertulis dengan cara membaca literature, tulisan, maupun dokumen yang dianggap peneliti berkenan dengan penelitian yang sedang diteliti.

Definisi oprasional dari variabel yang terdapat dalam penelitian ini adalah sebagai berikut :

1. Pemimpin

Menurut Hasibuan (2011:157), pemimpin adalah seseorang yang mempergunakan wewenang dan kepemimpinannya untuk mengarahkan orang lain serta bertanggung jawab atas pekerjaan orang tersebut dalam mencapai suatu tujuan.

2. Kinerja

Hasibuan (2011:94) mengemukakan bahwa kinerja adalah suatu hasil kerja yang dicapai seseorang dalam melaksanakan tugas-tugas yang dibebankan kepadanya yang didasarkan atas kecakapan, pengalaman dan kesungguhan serta waktu. Kinerja adalah merupakan gabungan dari tiga faktor penting, yaitu kemampuan dan minat seorang pegawai, kemampuan dan penerimaan atas penjelasan delegasi tugas, serta peran dan tingkat motivasi seorang pegawai, dan semakin tinggi ketiga faktor di atas, maka akan semakin besar pula kinerja dari pegawai yang bersangkutan.

Penelitian ini menggunakan metode deskriftif merupakan penelitian yang bersifat eksploratif bertujuan untuk menggambarkan keadaan status fenomena. Data yang telah dikumpulkan diolah dan disajikan secara sewajarnya, karena metode peneltian yang digunakan metode deskriptif, jadi seluruh rangkaian kegiatan proses penelitian dan hasil penelitian dilaksanakan secara serempak.

\section{Hasil Penelitian dan Pembahasan}

Hasil evaluasi kinerja pegawai Radio Swara Bersujud 89,8 FM menyebutkan bahwa kualitas penyiar belum sesuai dengan yang ditargetkan Radio Swara Bersujud 89,8 FM, hal ini dilihat dari masih adanya penyiar yang blank saat acara berlangsung, intonasi yang kurang jelas, dan penyiar melakukan penyiaran tidak sesuai rule penyiaran. Sejalan dengan permasalahan tersebut, hasil wawancara yang dilakukan terhadap pegawai Radio Swara Bersujud 89,8 FM terdapat keluhan yaitu tidak adanya pelatihan yang diberikan secara periodik untuk meningkatkan kualitas penyiar.

Adapun upaya yang telah dilakukan pimpinan Radio Swara Bersujud 89,8 FM dalam meningkatkan kinerja penyiar yaitu melalui :

\section{Orientasi Kerja}

Program ini dirancang untuk memberikan kesempatan bagi penyiar yang baru bergabung di Radio Swara Bersujud 89,8 FM untuk bisa menyesuaikan diri atau beradaptasi dengan lingkungan kerja yang baru. Orientasi disini yaitu Radio Swara Bersujud 89,8 FM memperlakukan pegawai baru (melatih penyiar ) untuk mengetahui informasi tentang organisasi penyiaran radio, pekerjaan, dan perilaku yang diharapkan. Tipe orientasi lebih mengarah kepada mempelajari tentang kebijakan dan prosedur di Radio Swara Bersujud 89,8 FM. Dalam proses orientasi, pegawai belajar bagaimana bekerja yang sesungguhnya yang didampingi oleh senior penyiar yang mengontrol sikap dan kinerjanya. Materi latihan akan banyak berkonsentrasi pada "Announcing Skill" yang didalamnya termasuk pemahaman spesifikasi lagu, teknik mixing, teknik vokal, teknik operating, dan lain-lain. Untuk waktunya ditetapkan dan terjadwal sesuai perencanaan, antara 1-2 bulan latihan di studio yang tidak on air. Jika dalam perjalanan orientasi pegawai baru tersebut cepat menguasai dan dianggap sudah layak on air walaupun belum 2 bulan, maka pegawai baru tersebut akan di test mengudara (trial on-air). Dan inilah yang disebut siaran perdana bagi 
pegawai baru di Radio Swara Bersujud 89,8 FM. Perjalanan siaran akan berdasarkan log siaran, dimana penyiar harus menyampaikan informasi, adlibs (Iklan baca), memutar spot iklan, dan lain-lain.

2. Memberikan teguran

Jika ada penyiar yang melakukan kesalahan atau bekerja tidak sesuai prosedur, maka pimpinan Radio Swara Bersujud 89,9 FM segera memberikan teguran langsung kepada penyiar tersebut. Tujuan dari peneguran langsung agar penyiar yang melakukan kesalahan dapat memberikan klarifikasi dengan benar, dan memberikan himbauan agar tidak mengulangi kesalahannya, kemudian berikan penyiar tersebut kesempatan untuk memperbaikinya.

Adapun upaya yang seharusnya dilakukan oleh pimpinan Radio Swara Bersujud 89,8 FM adalah sebagai berikut :

1. Pelatihan

Radio Swara Bersujud 89,8 memberikan pelatihan kepada pegawainya bukan hanya pada saat orientasi pegawai baru, tetapi pelatihan diberikan secara periodik sesuai dengan kebutuhan dari pegawai yang ada. Jika hasil dari evaluasi kinerja menunjukkan bahwa kinerja pegawai belum optimal, maka pihak Radio Swara Bersujud 89,8 FM hendaknya mengevaluasi kebutuhan pelatihan yang harus diberikan agar kinerja pegawai dapat meningkat. Pelatihan yang dimaksud adalah penyegaran pagi para penyiar agar lebih menguasai teknik penyiaran yang baik seperti artikulasi dan vocal, spontanitas yang baik, peka situasi, enjaga emosi, sense of humor, dan konsentrasi.

2. Rotasi Jabatan

Radio Swara Bersujud 89,8 FM membuat program rotasi jabatan. Dengan rotasi jabatan diharapkan agar pegawai memahami pelaksanaan berbagai tugas, agar ia memperoleh pengetahuan yang lebih luas mengenai berbagai jabatan. Hal ini juga untuk mengantisipasi rasa jenuh pada pegawai. Pada Radio Swara Bersujud 89,9 FM ada beberapa devisi siaran yang berbeda.

3. Promosi

Radio Swara Bersujud 89,8 FM membuat program promosi jabatan. Sasarannya adalah untuk mengembangkan pegawai sebab pegawai yang cukup berprestasi pada jabatannya harus dikembangkan dengan menegaskan ia untuk menerima tugas. Walaupun sama-sama penyiar tetapi di Radio Swara Bersujud 89,8 FM ada beberapa tingkatan penyiar diantaranya junior penyiar dan senior penyiar.

4. Konseling

Pimpinan memberikan konseling kepada pegawainya yang berhubungan dengan pelaksanaan pekerjaan, demi semakin terampilnya para karyawan yang bersangkutan. Pimpinan merupakan atasan langsung dari para penyiar, sehingga pimpinan mempunyai kapasitas untuk melakukan konseling. Konseling ini ditujukan kepada para penyiar yang melakukan kesalahan atau bekerja tidak sesuai prosedur. Dalam konseling, pimpinan akan memberikan masukan atau solusi terhadap para penyiar sesuai dengan permasalahannya.

Upaya yang diberikan oleh pimpinan Radio Swara Bersujud 89,8 FM selama ini masih belum efektif dalam meningkatkan kinerja karyawan, hal ini dilihat dari belum optimalnya kinerja karyawan yang ada. Jika hal ini dibiarkan terus-menerus maka kinerja organisasi akan menjadi turun. Agar hal tersebut tidak terjadi, maka hendaknya pimpinan Radio Swara Bersujud 89,8 FM melakukan tindakan perbaikan dari hasil evaluasi kinerja, agar kinerja pegawai dapat meningkat. 


\section{Kesimpulan}

1. Upaya yang selama ini dilakukan pimpinan Radio Swara Bersujud 89,8 FM dalam meningkatkan kinerja pegawai adalah melalui orientasi kerja dan pemberian teguran.

2. Upaya yang seharusnya dilakukan pimpinan Radio Swara Bersujud 89,8 FM adalah pelatihan, rotasi jabatan, promosi, konseling

\section{DAFTAR PUSTAKA}

Ambar, Teguh Sulistiyani dan Rosidah, 2012, Manajemen Sumber Daya Manusia, Graha Ilmu, Yogyakarta

Ahmad, Tohardi, 2012, Pemahaman Praktis Manajemen Sumber Daya Manusia, Universitas Tanjung Pura, Mandar Maju, Bandung

Apriyanti, Dini, 2015, Upaya Pimpinan Dalam Meningkatkan Kinerja Penyiar Radio RRI Pro-4 Malang Jawa Timur, Sekolah Tinggil Ilmu Ekonomi Malangkucecwara, Malang

Effendy, 2011, Ilmu Komunikasi: Teori dan Prakteknya, Remaja Rosdakarya, Bandung

Eugene Mckenna dan Nic Beech, 2010, Manajemen Sumber Daya Manusia, Andi, Yogyakarta

Hariandja, Marihot T.E, 2011, Manajemen Sumber Daya Manusia, Grasindo, Jakarta Hasibuan, Malayu S.P, 2011, Manajemen Sumber Daya Manusia, Bumi Aksara, Jakarta Mangkunegara, Anwar Prabu, 2011, Evaluasi Kinerja Sumber Daya Manusia, Rosda Karya, Bandung

Moleong, Lexy J., 2012, Metodologi Penelitian Kualitatif, PT Remaja Rosdakarya, Bandung M. Manullang, 2014, Dasar-dasar Manajemen, Gajah Mada University Press, Yogyakarta Nawawi, Hadari, 2012, Metode Penelitian Bidang Sosial, Mada University Press, Yogyakarta

Oktavia, Ana, 2016, Upaya Pimpinan Dalam Meningkatkan Kinerja Penyiar Pada Radio Suara Serasi 94 FM Semarang, Universitas Semarang, Semarang

Poerwandari, 2013, Pendekatan Kualitatif untuk Penelitian Perilaku Manusia, LPSP3 UI, Jakarta

Panggabean, 2010, Manajemen Sumber Daya Manusia, Ghalia Indonesia, Bogor

Pratama, Rio, 2013, Upaya pimpinan dalam meningkatkan kinerja penyiar pada Radio Mahameru FM Kediri, Universitas Islam Kediri, Kediri

Rachmawati, 2008, Manajemen Sumber Daya Manusia, Andi, Yogyakarta

Ranupandjojo, Heidjrachman dan Husnan Suad, 2014, Manajemen Persoalia, BPFE, Yogyakarta

Siagian, Sondang P., 2012, Manajemen Sumber Daya Manusia, PT Bumi Aksara, Jakarta

Simanjuntak, 2014, Manajemen Dan Evaluasi Kinerja, Fakultas Ekonomi Universitas Indonesia, Jakarta

Simamora, Henry, 2013, Manajemen Sumber Daya Manusia, STIE YKPN, Yogyakarta

Siswanto, Sastrohadiwiryo, 2012, Manajemen Tenaga Kerja Indonesia ,Pendekatan Administrasi dan Operasional, Bumi Aksara, Jakarta

Sugiyono, 2008, Metode Penelitian Kuantitatif - Kualitatif dan R\&D, Alfabeta, Bandung

Supriyanto, 2013, Metodologi Riset Manajemen Sumber daya Manusia, UIN Maliki Press, Malang

Torang, Syamsir, 2013, Organisasi dan Manajemen (Perilaku, Struktur, Budaya \& Perubahan Organisasi), Alfabeta, Bandung

Veithzal, Rivai, 2012, Manajemen Sumber Daya Manusia Untuk Perusahaan, PT. Raja GrafindoPersada, Jakarta

Zagladi, Arief Noviarakhman, Fredy Jayen, Sutrisno dan Melania, 2012, Pedoman Penulisan Skripsi STIE Pancasetia Banjarmasin, Pancasetia, Banjarmasin 